\title{
Chemical geodynamics with eclogite - P. Gast Medal Lecture
}

\author{
SONJA AULBACH ${ }^{1}$, NICHOLAS T. ARNDT ${ }^{2}$, AXEL \\ GERDES $^{3}$, LARRY M. HEAMAN ${ }^{4}$, HEIDI E. HÖFER ${ }^{5}$, \\ VINCENZO STAGNO ${ }^{6}$, RICHARD A STERN ${ }^{7}$, FANUS \\ VILJOEN $^{8}$ AND ALAN B. WOODLAND ${ }^{5}$
}

${ }^{1}$ Goethe University Frankfurt

${ }^{2}$ University of Grenoble

${ }^{3}$ Goethe Universität Frankfurt

${ }^{4}$ University of Alberta

${ }^{5}$ Goethe University of Frankfurt

${ }^{6}$ Sapienza University of Rome

${ }^{7}$ 1-26 ESB, Department of Earth \& Atm Sciences

${ }^{8}$ University of Johannesburg

Presenting Author: s.aulbach@em.uni-frankfurt.de

Mid-ocean ridge basalt (MORB), the melting product of the ambient convecting mantle, subducts at convergent margins. Some of this material returns to the surface as tectonically exhumed or xenolithic "oceanic" eclogite.

Oceanic eclogite is a key indicator of past subduction and can also be used to investigate its source in the convecting mantle as far back as $\sim 3 \mathrm{Ga}$. However, the eclogite record is obscured by seafloor weathering and processing in subduction zones. When samples that were metasomatised or derived from strongly differentiated or cumulate protoliths are excluded, $\mathrm{V} / \mathrm{Sc}$ and $\mathrm{Fe}^{3+} / \Sigma \mathrm{Fe}$ in eclogites are robust geochemical proxies of the oxygen fugacity $\left(\mathrm{fO}_{2}\right)$ of the ambient mantle. Both ratios are higher in post-Archaean than in most Archaean eclogites, suggesting a secular increase in the convecting mantle's $f \mathrm{O}_{2}$. The moderately incompatible elements, $\mathrm{Ti}$ and $\mathrm{Sm}$, record the melt fraction by which the eclogites' protoliths formed, and indirectly, the mantle potential temperature (TP). Their abundances increase through time, consistent with cooling, but require $\mathrm{TP}$ at $3 \mathrm{Ga}$ only some $100-150^{\circ} \mathrm{C}$ higher than today. Extremely low ${ }^{87} \mathrm{Sr} /{ }^{86} \mathrm{Sr}(\leq 0.7007)$ in some eclogites suggests moderate depletion of ambient mantle by $3 \mathrm{Ga}$. These parameters $\left(f \mathrm{O}_{2}, \mathrm{TP}\right.$, composition) affect mantle dynamics and melting relations, plate strength and the redox state of volcanic gases, with strong impacts on the evolution of Earth and life.

Oxybarometry also shows that after metamorphism, the vast majority of eclogites, including those showing evidence of seafloor weathering (non-mantle $\delta^{18} \mathrm{O}$ ), record $f \mathrm{O}_{2}$ lower than both modern MORB and its Archaean equivalent. The low $f \mathrm{O}_{2}$ stabilises diamond relative to oxidised carbon species, presenting a pathway for deep carbon recycling, and indicating little oxidising power for deeply subducted oceanic crust. 